FILOLOGIJA 69, Zagreb 2017.

\title{
Barbara Balantič
}

UDK 81'374:81'367.625=163.6

https://dx.doi.org/10.21857/moxpjhgexm

Pregledni članak

Primljen 30.IV.2017.

Prihvaćen za tisak 26.IX.2017.

Filozofická fakulta Univerzity Karlovy

nám. Jana Palacha 2, CZ-11638 Praha 1

barbara.balantic@gmail.com

\section{GLAGOLI V PRIMERJALNEM INDEKSU K SLOVARJEM OBDELANEM V OKVIRU KOMISIJE ZA CERKVENOSLOVANSKE SLOVARJE PRI MEDNARODNEM KOMITEJU SLAVISTOV}

Prispevek se posveča informacijam o starocerkvenoslovanskih glagolih, ki jih je mogoče pridobiti v Primerjalnem indeksu k slovarjem obdelanem $v$ okviru Komisije za cerkvenoslovanske slovarje pri Mednarodnem komiteju slavistov (t. i. Srovnávací index k slovníkům zpracovávaným v rámci Komise pro církevněslovanské slovníky u MKS; ured. Zdenka Ribarova, 2007-), ki s primerjalnega vidika pregledno na enem mestu združuje in predstavlja med drugim različne podobe glagolov oz. glagolskih oblik posameznih starocerkvenoslovanskih slovarjev in cerkevnoslovanskih redakcijskih slovarjev (vključuje: Старославянский словарь (= SS; po rokopisih X.XI. stol.; Moskva 1994), Slovníkjazyka staroslověnského (=SJS; Praga 19581997, 2006), Rječnik crkvenoslavenskoga jezika hrvatske redakcije (= RCJH; Zagreb, od 1991), Речник на ирковнословенскиот јазик од македонска редакциија (= RCJM; Skopje, od 2006), Речник ирквенословенског језика српске редакције и Српско-словенског јеванђељског речника (= SRJ; ро neizdanem geslovniku, Beograd) in Словарь древнерусского языкка XIXIV. stol. (= SDRJ; Moskva, od 2007). Znotraj gesel je opaziti razlike na večih jezikovnih ravninah. Največ razlik je opaziti na grafemski rav$\mathrm{ni}$, kjer se pojavljajo različni grafemi za isti fonem in so v posameznih primerih odraz določenih glasoslovnih sprememb (npr. denazalizacije, sovpada oz. onemitve polglasnikov, sovpada ы z и, soglasniških sprememb itd). Te razlike in spremembe pa pogosto vplivajo na oblikoslovne značilnosti (npr. različno podobo končnic, dubletne oblike). Zaslediti je tudi razlike $\mathrm{v}$ glagolski refleksivnosti in določitvi glagolskega aspekta. Po rezultatih sodeč omenjeni indeks predstavlja izčrpen register starocerkvenoslovanskega leksikografskega korpusa in nam ponuja veliko možnosti za nadaljnje raziskave. 
Barbara Balantič: Glagoli v primerjalnem indeksu $k$ slovarjem obdelanem v okviru Komisije... FILOLOGIJA 69(2017), 1-21

\section{Uvod}

Prispevek obravnava informacije o glagolih v Primerjalnem indeksu $k$ slovarjem obdelanem v okviru Komisije za cerkvenoslovanske slovarje ${ }^{1}$ pri Mednarodnem komiteju slavistov oz. v t. i. Srovnávacím indexu $k$ slovníküm zpracovávaným v rámci Komise pro církevněslovanské slovníky u MKS pod vodstvom Zdenke Ribarove (od leta 2007 dalje) z namenom, da s primerjalnega vidika pregledno na enem mestu združi in predstavi leksikalne specifičnosti posameznih cerkvenoslovanskih slovarjev. V omenjenem indeksu so torej pregledno na enem mestu združena gesla posameznih starocerkvenoslovanskih slovarjev in cerkevnoslovanskih redakcijskih slovarjev. Vključuje:

- Старославянский словарь (= SS; po rokopisih X.-XI. stol.; Moskva 1994),

- Slovník jazyka staroslověnského (= SJS; Praga 1958-1997, 2006),

- Rječnik crkvenoslavenskoga jezika hrvatske redakcije (= RCJH; Zagreb, od 1991),

- Речник на ирковнословенскиот јазик од македонска редакција (= RCJM; Skopje, od 2006),

- Речник ирквенословенског језика српске редакције и Српско-словенског јеванђељског речника (= SRJ, od 2007; po neizdanem geslovniku, Beograd oz. SRR = Ogled srpskog redakcijskog rečnika),

- Словарь древнерусского языка XI.-XIV. stol. (= SDRJ; Moskva, od 1988).

V indeks je torej vključenih 6 slovarjev. ${ }^{2}$ Prispevek temelji na najnovejši verziji indeksa, izdani leta 2015 v Skopju, ki vsebuje gesla od a do z. ${ }^{3}$ Namen prispevka je predstaviti različne podobe starocerkvenoslovanskih oz. cerkvenoslovanskih glagolov oz. glagolskih oblik posameznih starocerkvenoslovanskih in cerkvenoslovanskih redakcijskih slovarjev zbranih

\footnotetext{
${ }^{1}$ Komisija za cerkvenoslovanske slovarje je bila ustanovljena leta 1958 na 4. mednarodni kongresu slavistov v Moskvi z namenom, da podpre in koordinira delo posameznih slovarskih projektov, s katerimi se ukvarjajo posamezne nacionale ekipe, in da razpravlja o načinih razrešitve konkretnih problemov cerkvenoslovanske leksikografije.

${ }^{2}$ SS in SJS sta izdana v celoti, medtem ko so ostali 4 slovarji še v nastajanju. Obstoječi indeks je v primeru SS, SJS in SDRJ ( $a$-svbtětisę) usklajen z uradno izdajo, v dveh slovarjih so informacije pridobljene iz deloma izdane in deloma še neizdane verzije, to sta RCJH (I. $a$-vrědb, II. vrěd bnb-zapovědnica) in RCJM (I. $a-b$., II. v-vrsklaněti sę), medtem ko so za SRJ podatki pridobljeni še neizdanega geslovnika.

${ }^{3}$ Dostopna tudi na spletnem naslovu: http://ical.manu.edu.mk/books/Sporedben \%20 indeksMANU.pdf.
} 
Barbara Balantič: Glagoli v primerjalnem indeksu k slovarjem obdelanem v okviru Komisije... FILOLOGIJA 69(2017), $1-21$

$\mathrm{v}$ indeksu, prikazati razlike med uzusi oz. normalizacijami posameznih slovarjev in s tem tudi pravila posameznih redakcij. Pri nekaterih glagolih je znotraj gesel med posameznimi slovarji opaziti kar nekaj razlik. Večinoma gre za grafemske razlike, ki so včasih odraz fonoloških sprememb, pogosto pa vplivajo tudi na morfološke značilnosti, opaziti je tudi druge razlike, in sicer razlike $\mathrm{v}$ refleksivnosti posameznih glagolov in razlike $\mathrm{v}$ določitvi glagolskega aspekta. V nadaljevanju so $\mathrm{v}$ tabelaričnih prikazih predstavljene vse razlike, ki se pojavljajo pri posameznih glagolih znotraj gesel od a do z, za boljšo ponazoritev pa je pri vsaki razliki podanih tudi nekaj primerov iz indeksa.

\section{Grafemske razlike}

Gesla v indeksu so zapisana v cirilici in prikazujejo normalizirano stanje posameznih slovarjev, ki so prav tako vsa normalizirana v cirilici, kljub temu da seveda črpajo material tudi iz glagolskih spomenikov. Grafemske razlike so včasih tudi odraz fonoloških sprememb, a vendar o fonetičnih razlikah ne moremo z gotovostjo govoriti. Grafemskih razlik znotraj gesel je veliko. Pojavljajo se tako pri samoglasnikih kot soglasnikih. V nadaljevanju bodo posamično predstavljene vse grafemske razlike, ki se pojavljajo v indeksu.

\section{1}

Za stcsl. $y$ znotraj posameznih gesel zasledimo reflekse prikazane v Tabeli 1. Stcsl. y prisoten $v$ večini slovarjev (v SRJ in SDRJ v grafemski različici d), le v RCJH je poenoten z i-jem.

Tabela 1: Refleksi za stcsl. $y$

\begin{tabular}{|c|c|c|c|c|c|c|}
\hline s. ${ }^{*}$ & SS & SJS & RCJH & RCJM & $\begin{array}{c}\text { SRJ (oz. } \\
\text { SRR) }\end{array}$ & SDRJ \\
\hline & bI & ҺI & $\mathrm{H}$ & hI & bl & bI \\
\hline ЫІ & $\begin{array}{l}\text { zакрытн, } \\
\text {-крљыњ, } \\
\text {-кръыєшн } p f\end{array}$ & $\begin{array}{l}\text { zакрытн, } \\
\text {-кръак, } \\
\text {-крълєшн } p f\end{array}$ & $\begin{array}{l}\text { zакрнтн, } \\
\text {-крню, } \\
\text {-крнєшн } p f\end{array}$ & $\begin{array}{l}\text { zакрытн, } \\
\text {-крых, } \\
\text { - крыєтъ }\end{array}$ & $\begin{array}{l}\text { zакрьттн, } \\
\text {-крьію, } \\
\text {-крьІєшн } p f\end{array}$ & $\begin{array}{l}\text { zакры|тн, -ю, } \\
\text {-юШН } p f \\
\text { zАКрь| ТнсА, } \\
\text {-юСА, -юШНСА } p f\end{array}$ \\
\hline
\end{tabular}

${ }^{*}$ s. = starocerkvenoslovanski 
Barbara Balantič: Glagoli v primerjalnem indeksu $k$ slovarjem obdelanem v okviru Komisije... FILOLOGIJA 69(2017), 1-21

\section{2}

Za stcsl. $e$ in je imajo posamezni slovarji reflekse prikazane v Tabeli 2. Oba nosniška grafema - tj. a in jotirano varianto ז vsebujeta SS in SJS, medtem ko se v RCJM v vseh pozicijah uporablja grafem $\AA$. V ostalih redakcijskih slovarjih se pojavljajo že denazalizirane oblike, pri čemer $\mathrm{v}$ SDRJ le v poziciji za $\check{c}, \check{z}, \breve{s}, c$ in $j$.

Tabela 2: Refleksi za stcsl. $e$ in je

\begin{tabular}{|c|c|c|c|c|c|c|}
\hline s. & SS & SJS & RCJH & RCJM & $\begin{array}{l}\text { SRJ(oz. } \\
\text { SRR) }\end{array}$ & SDRJ \\
\hline \multirow{3}{*}{ A } & $\mathbf{A}$ & $\mathbf{A}$ & $\epsilon$ & $A$ & $\epsilon$ & $\mathrm{A}, \boldsymbol{A}$ za $\check{c}, \check{z}, \check{s}, c$ \\
\hline & $\begin{array}{l}\text { ЖАтн, жьнІа, } \\
\text { жьнєшн ipf }\end{array}$ & $\begin{array}{l}\text { ЖАтн, жьнІа, } \\
\text { жьНІшН ipf }\end{array}$ & $\begin{array}{l}\text { Жетн, } \\
\text { Ж’ню, } \\
\text { ж’нєшн ipf }\end{array}$ & $\begin{array}{l}\text { жАтн, } \\
\text { жьнх, } \\
\text { жьнєть } \\
\text { ipf }\end{array}$ & $\begin{array}{l}\text { Жетн, жьню, } \\
\text { жьнюшн ipf }\end{array}$ & 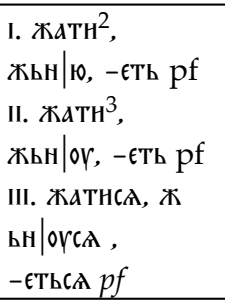 \\
\hline & $\begin{array}{l}\text { ГААдАТН, } \\
\text {-Ањ, -АєШН } \\
\text { ipf }\end{array}$ & $\begin{array}{l}\text { ГААдаТН, } \\
\text {-ААњХ, } \\
\text {-АаєШН ipf }\end{array}$ & $\begin{array}{l}\text { ГАєААТН, } \\
-А ю, \\
-А є Ш Н / \\
-А \mu ь, \\
\text {-Ашн ipf }\end{array}$ & $\begin{array}{l}\text { ГААААТТ, } \\
\text {-ААХ, } \\
\text {-ААЕТЪ ipf }\end{array}$ & $\begin{array}{l}\text { гАєААТН, -Аю, } \\
\text { - АєШН ipf } \\
\text { var ad } \\
\text { ГАєААТН (сє) }\end{array}$ & $\begin{array}{l}\text { ГАААА|ТН, -ю, } \\
\text {-юТЬ ipf }\end{array}$ \\
\hline & FA & rA & t & $A$ & If & ra \\
\hline IA & $\begin{array}{l}\text { въспрнгАтн, } \\
\text {-Прннщж, } \\
\text {-Прннцєшн } \\
p f\end{array}$ & $\begin{array}{l}\text { въспрнгАтн, } \\
\text {-Прннцж, } \\
\text {-Прннцєшн } \\
p f\end{array}$ & $\begin{array}{l}\text { вспрнБтн, } \\
\text {-прнщог, } \\
\text {-прнцєшн } \\
p f\end{array}$ & 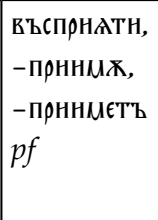 & $\begin{array}{l}\text { вьспрннтн, } \\
\text {-прннцог, } \\
\text {-прннцешн } \\
p f\end{array}$ & 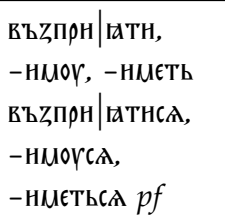 \\
\hline
\end{tabular}


Barbara Balantič: Glagoli v primerjalnem indeksu k slovarjem obdelanem v okviru Komisije... FILOLOGIJA 69(2017), 1-21

\section{3}

Za stcsl. $Q$ in jo uporabljajo slovarji reflekse prikazane v Tabeli 3. Denazalizirane oblike z $u$ oz. ju imajo RCJH, SRJ in SDRJ, ostali slovarji ohranjajo oblike z nazali $Q$ in $j o$, pri čemer v RCJM zopet v vseh pozicijah uporablja grafem $\mathrm{n}$.

Tabela 3: Refleksi za stcsl. $Q$ in $j Q$

\begin{tabular}{|c|c|c|c|c|c|c|}
\hline s. & SS & SJS & $\mathrm{RCJH}$ & RCJM & $\begin{array}{l}\text { SRJ(oz. } \\
\text { SRR) }\end{array}$ & SDRJ \\
\hline & $\pi$ & $\pi$ & or & $\pi$ & or & or \\
\hline$\pi$ & $\begin{array}{l}\text { АХТн, АъМХ, } \\
\text { АъМєШН } \\
\text { ipf }\end{array}$ & $\begin{array}{l}\text { АХтн, АъМх, } \\
\text { АъМєШН } \\
\text { ipf }\end{array}$ & $\begin{array}{l}\text { АОГТн, АMOГ, } \\
\text { АМЕШН } \\
\text { ipf }\end{array}$ & $\begin{array}{l}\text { АХТН, АъМХ, } \\
\text { АЪМЕШН var } \\
\text { АХТН СА } \\
\text { ipf }\end{array}$ & $\begin{array}{l}\varnothing|| \text { SRR } \\
\text { Аоүтн, } \\
\text { Аьмог, } \\
\text { Аьмєшн } \\
\text { ipf }\end{array}$ & $\begin{array}{l}\text { Аоүтн, Аъм|оr, } \\
\text {-єТъ } \\
\text { ipf }\end{array}$ \\
\hline & $1 x$ & $1 x$ & 10 & $1 x$ & 10 & 10 \\
\hline $1 \times$ & 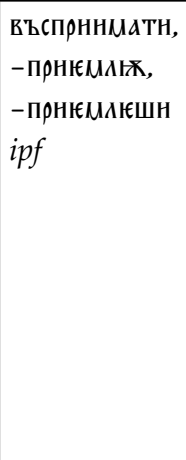 & 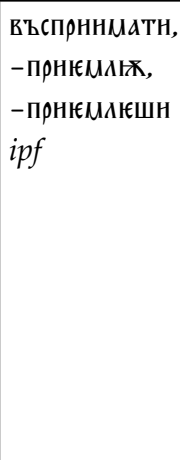 & $\begin{array}{l}\text { вспрнєМАТн/ } \\
\text { вспрннМатн } \\
\text {-єМАю, } \\
\text {-єМлєШН ipf }\end{array}$ & 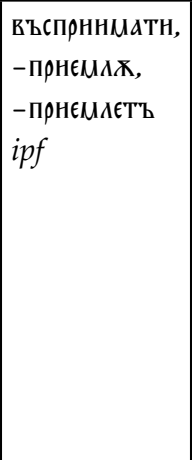 & 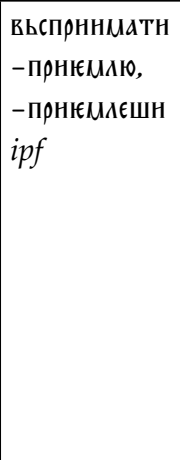 & 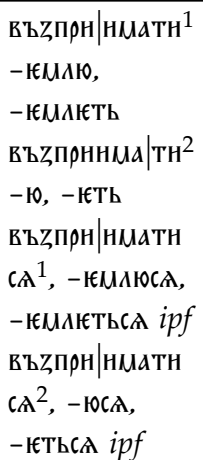 \\
\hline
\end{tabular}


Barbara Balantič: Glagoli v primerjalnem indeksu k slovarjem obdelanem v okviru Komisije... FILOLOGIJA 69(2017), 1-21

\section{4}

Za stcsl. polglasnike imajo posamezni slovarji reflekse prikazane v Tabeli 4. Stcsl. в in ъ sta v večini slovarjev nespremenjena, z izjemo SRJ, kjer ъ sovpade $\mathrm{z}$ b, in $\mathrm{RCJH}$, kjer se $\mathrm{v}$ krepki poziciji vokalizirata, v šibki pa sovpadeta $\mathrm{V}$ b oz. ošibita ali onemita.

Tabela 4: Refleksi za stcsl. polglasnike

\begin{tabular}{|c|c|c|c|c|c|c|}
\hline $\mathrm{S}$. & SS & SJS & $\mathrm{RCJH}$ & RCJM & SRJ & SDRJ \\
\hline \multirow{5}{*}{ b } & b & b & $\begin{array}{c}\mathrm{b}>\mathrm{a} ; \mathrm{b}> \\
\varnothing, \stackrel{\mathrm{b}}{\mathrm{b}}\end{array}$ & b & b & $\mathbf{b}$ \\
\hline & $\begin{array}{l}\text { ЖАтн, } \\
\text { жьнІх, } \\
\text { жьнюшн } \\
i p f\end{array}$ & $\begin{array}{l}\text { ЖАтн, } \\
\text { жьнІх, } \\
\text { жьнюєшн } \\
\text { ipf }\end{array}$ & $\begin{array}{l}\text { Жетн, ж’ню, } \\
\text { Ж’нєШН ipf }\end{array}$ & $\begin{array}{l}\text { ЖАТн, ЖьнХ, } \\
\text { ЖьнєТъ } \\
\text { ipf }\end{array}$ & $\begin{array}{l}\text { Жетн, Жьню, } \\
\text { ЖьнєШн ipf }\end{array}$ & 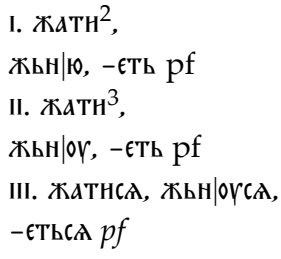 \\
\hline & $\begin{array}{l}\text { АdTH, } \\
\text { АdMь, } \\
\text { АdCH pf }\end{array}$ & $\begin{array}{l}\text { ААТн, } \\
\text { ААUь, } \\
\text { ААCH } p f\end{array}$ & $\begin{array}{l}\text { Аатн, } \\
\text { АdUь, ААсн } \\
\text { vel ААшн } p f\end{array}$ & $\begin{array}{l}\text { АATH, АAMь, } \\
\text { ААСТT pf }\end{array}$ & $\begin{array}{l}\text { АATH, АAML, } \\
\text { АACH } p f\end{array}$ & $\begin{array}{l}\text { да|тн, - } \mathrm{Mb}, \\
- \text {-сть } p f\end{array}$ \\
\hline & $\begin{array}{l}\text { ВЪYАТН, } \\
\text { - ҮЬНХ, } \\
\text {-ҮЬНєШН } \\
\text { pf }\end{array}$ & $\begin{array}{l}\text { ВЪYАТН, } \\
\text {-ҮЬНХ, } \\
\text {-ҮЬНєШН } \\
\text { pf }\end{array}$ & $\begin{array}{l}\text { вҮЕТН, } \\
\text { в'ҮнОГ, } \\
\text { в’ҮНЕШН pf }\end{array}$ & $\begin{array}{l}\text { ВЪYАTН, } \\
\text {-ҮЬНХ, } \\
\text {-ҮЬНЕТЬ } p f\end{array}$ & $\begin{array}{l}\text { ВЬҮЕТН, } \\
\text {-ҮЬНОГ, } \\
\text {-ҮЬНЕШН } p f\end{array}$ & $\begin{array}{l}\text { въчатн, } \\
\text { въчьн|ог, -єТъ } \\
p f \| \text { corr ad }\end{array}$ \\
\hline & $\begin{array}{l}\text { 弓ьрьтн, } \\
\text { Zьрюх, } \\
\text { Zьрншн } \\
\text { ipf }\end{array}$ & $\begin{array}{l}\text { zьрьтн, } \\
\text { zьрњк, } \\
\text { zьрншн ipf }\end{array}$ & $\begin{array}{l}\text { zрьтн, } \\
\text { zрю, зрншн } \\
\text { ipf }\end{array}$ & $\begin{array}{l}\text { Zьрьтн, зьрх, } \\
\text { ъьрнть ipf }\end{array}$ & $\begin{array}{l}\text { zрьтн, -рю, } \\
\text {-рншн ipf } \| \\
\text { SRR var } \\
\text { zьрьтн, } \\
\text {-рю, -рншн }\end{array}$ & 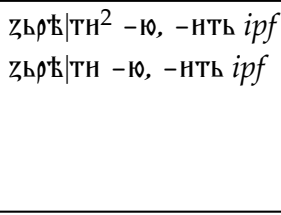 \\
\hline \multirow[b]{2}{*}{$\mathbf{b}$} & $\mathbf{b}$ & $\mathbf{b}$ & $\varnothing, ', \mathrm{~b}, \boldsymbol{a}$ & $\mathbf{b}$ & b & $\mathbf{b}$ \\
\hline & $\begin{array}{l}\text { Гънатн, } \\
\text { жєнХ, } \\
\text { жєнєШН } \\
i p f\end{array}$ & $\begin{array}{l}\text { Гънатн, } \\
\text { жєнХ, } \\
\text { жєнєшн ipf }\end{array}$ & 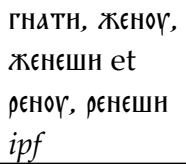 & $\begin{array}{l}\text { Гънатн, } \\
\text { ЖєнХ, } \\
\text { ЖєнєТТ } \\
i p f\end{array}$ & $\begin{array}{l}\text { Гьнатн, } \\
\text { жєноҮ, } \\
\text { жєнєшн ipf }\end{array}$ & $\begin{array}{l}\text { Гънатн, } \\
\text { Жєноү, } \\
\text { ЖєнєТь } \\
\text { ipf }\end{array}$ \\
\hline
\end{tabular}


Barbara Balantič: Glagoli v primerjalnem indeksu k slovarjem obdelanem v okviru Komisije... FILOLOGIJA 69(2017), $1-21$

\section{5}

Za stcsl. je in ja se znotraj gesel pojavljajo refleksi prikazani v Tabeli 5. Vsi slovarji imajo stcsl. glasova je in ja. Posebnosti najdemo v RCJH, ki uporablja za glas je grafem $€$, za glas ja pa grafem $ъ$, in RCJM, ki ima grafem $є$ ohranjen le za sprednjimi samoglasniki, medtem ko se za zadnjimi soglasniki glas zapisuje $\mathrm{z} \epsilon$.

Tabela 5: Refleksi za stcsl. je in ja

\begin{tabular}{|c|c|c|c|c|c|c|}
\hline S. & SS & SJS & RCJH & RCJM & $\begin{array}{c}\text { SRJ (oz. } \\
\text { SRR) }\end{array}$ & SDRJ \\
\hline & IE & IE & Є ШLEIA & $\epsilon$, If & If & If \\
\hline IE & $\begin{array}{l}\text { воюв АТН, } \\
\text { воююх, } \\
\text { воююшШн } \\
\text { ipf }\end{array}$ & $\begin{array}{l}\text { воюв } а \text { ТН, } \\
\text { воююа, вою } \\
\text { єШн ipf }\end{array}$ & $\begin{array}{l}\text { воєв } А \text { ТН, } \\
\text { воюю, вою } \\
\text { єШН ipf }\end{array}$ & $\begin{array}{l}\text { воєЕАТН, } \\
\text { вОюЮХ, } \\
\text { вОюЕТЬ ipf }\end{array}$ & $\begin{array}{l}\varnothing \| \text { SRR } \\
\text { воюв } а \text { Тн, } \\
\text { воюю, воююшн } \\
\text { ipf }\end{array}$ & $\begin{array}{l}\text { во|ювАТН, -юю, } \\
\text {-ююТЬ ipf } \\
\text { во|юЕАТНСА, -юю } \\
\text { СА, -ююТЬСА ipf }\end{array}$ \\
\hline & Id & ld & t [ja] & Id & Id & Id \\
\hline la & $\begin{array}{l}\text { въдаґтн, } \\
\text {-ААҢХ, } \\
\text {-ААєшН } \\
\text { ipf }\end{array}$ & $\begin{array}{l}\text { въдАґтн, } \\
\text {-ААҢж, } \\
\text {-Адњшн } \\
\text { ipf }\end{array}$ & $\begin{array}{l}\text { вдафтТ, } \\
\text { вдаю, } \\
\text { вдаєШН ipf }\end{array}$ & $\begin{array}{l}\text { въдағаТН, } \\
\text {-ААХ, } \\
\text {-ААєТТ } \\
\text { ipf }\end{array}$ & $\begin{array}{l}\text { вьдағатн, } \\
\text {-дАю, -даюшн } \\
\text { ipf (var ad } \\
\text { вьдаґтн сє) }\end{array}$ & $\begin{array}{l}\text { въда|ютт, } \\
\text {-ю, -ють } i p f\end{array}$ \\
\hline
\end{tabular}

\section{6}

Za stcsl. $d z$ se v slovarjih pojavljajo refleksi zabeleženi v Tabeli 6. Stcsl. fonem $d z$ se ohrani v SS, SJS in RCJM, v ostalih redakcijskih slovarjih pa preide $\mathrm{v} z$.

Tabela 6: Refleksi za stcsl. $d z$

\begin{tabular}{|c|c|c|c|c|c|c|}
\hline S. & SS & SJS & RCJH & RCJM & SRJ (oz. SRR) & SDRJ \\
\hline & $S$ & $S$ & Z & $S$ & Z & Z \\
\hline$S$ & $\begin{array}{l}\text { АБНSАТН, } \\
\text { АБНЖХ, } \\
\text { АБНЖЕШН/ } \\
\text { АБНSАІХ, } \\
\text { АБНSАєШн ipf } \\
\text { || etiam refl }\end{array}$ & 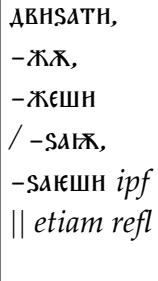 & $\begin{array}{l}\text { АвнZатн, } \\
\text {-аю, -аєшн } \\
\text { / Авнжог, } \\
\text { Авнжєшн } \\
\text { ipf || etiam } \\
\text { refl }\end{array}$ & 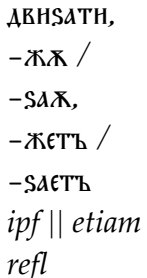 & $\begin{array}{l}\text { АБНZатН, АБНжоК, } \\
\text { АБНжєШН var ad } \\
\text { АБНZатН (сє) ipf } \| \\
=S R R\end{array}$ & $\begin{array}{l}\text { АВНZа|ТН, } \\
\text {-ю, -ІЕТЬ ipf }\end{array}$ \\
\hline
\end{tabular}


Barbara Balantič: Glagoli v primerjalnem indeksu $k$ slovarjem obdelanem v okviru Komisije... FILOLOGIJA 69(2017), 1-21

\section{7}

Za stcsl. soglasnika št, žd znotraj posameznih gesel zasledimo reflekse prikazane v Tabeli 7. Stcsl. fonema št in $\check{z} d$ imajo torej vsi slovarji, razen SDRJ, ki za stcsl. št vsebuje dubletne oblike - tj. starejši št in novejši $\check{c}$, za stcsl. $\check{z} d$ pa povsod novejši $\check{z}$.

Tabela 7: Refleksi za stcsl. št in $\check{z} d$

\begin{tabular}{|c|c|c|c|c|c|c|}
\hline S. & SS & SJS & RCJH & RCJM & $\begin{array}{l}\text { SRJ (oz. } \\
\text { SRR) }\end{array}$ & SDRJ \\
\hline & Щ & Щ & 廿 & Щ & щ & $\mathrm{Y} / \Psi$ \\
\hline 廿 & 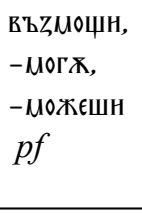 & $\begin{array}{l}\text { въzМочн, } \\
- \text { Мггх, } \\
- \text {-ожєшн } \\
p f\end{array}$ & 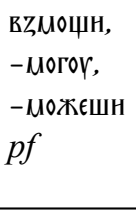 & $\begin{array}{l}\text { въzмощн, } \\
\text {-Могж, } \\
\text {-Можетъ } p f\end{array}$ & $\begin{array}{l}\text { вьзМоџн, } \\
\text {-могог, } \\
\text {-можєшн } \\
p f\end{array}$ & 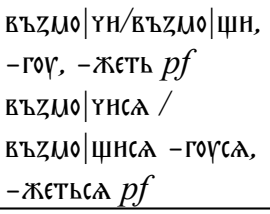 \\
\hline & жA & жA & жA & жA & ЖA & ж \\
\hline ЖA & 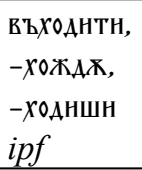 & 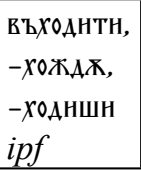 & $\begin{array}{l}\text { вХОАНТН, } \\
\text { вХОжАю, } \\
\text { вХОдНШН } \\
\text { ipf }\end{array}$ & $\begin{array}{l}\text { въХОАНТН, } \\
\text {-ХОжАХ, } \\
\text {-ХОАНТъ ipf }\end{array}$ & $\begin{array}{l}\text { вьХОАНТН, } \\
\text {-ХОЖАОУ, } \\
\text {-ХОАНШН } \\
\text { ipf }\end{array}$ & $\begin{array}{l}\text { въ } х 0 \mid \text { Антн, -жог, } \\
\text {-Анть ipf }\end{array}$ \\
\hline
\end{tabular}

2.8

Za stcsl. sklop -zdr- znotraj gesel opazimo reflekse zabeležene v Tabeli 8. Sklop -zdr- je večinoma prsoten v vseh slovarjih, le v RCJH in SDRJ se pojavljajo oblike $\mathrm{z}-z r-$.

Tabela 8: Refleksi za stcsl. sklop - $z d r-$

\begin{tabular}{|c|c|c|c|c|c|c|}
\hline S. & SS & SJS & $\mathrm{RCJH}$ & RCJM & $\begin{array}{c}\text { SRJ (oz. } \\
\text { SRR) }\end{array}$ & SDRJ \\
\hline & ZAP & ZAP & ZP & ZAP & ZAP & $\mathrm{ZP}$ \\
\hline $\begin{array}{c}\text { sklop } \\
\text { ZAP }\end{array}$ & $\begin{array}{l}\text { въҚАРЫАА- } \\
\text { ТН, - АњХ, } \\
\text { - АєШН } \\
p f\end{array}$ & $\begin{array}{l}\text { въҚАрҺІААТН, } \\
\text {-ААҢХ, } \\
\text {-ААњШН } \\
p f\end{array}$ & 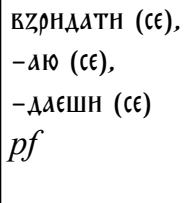 & $\begin{array}{l}\text { ВЪЪАРЪІААТН, } \\
\text {-ААХ, } \\
\text {-ААєТЪ } \\
p f\end{array}$ & 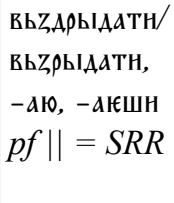 & 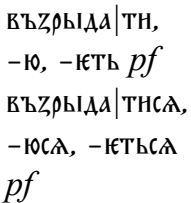 \\
\hline
\end{tabular}


Barbara Balantič: Glagoli v primerjalnem indeksu k slovarjem obdelanem v okviru Komisije... FILOLOGIJA 69(2017), 1-21

\section{9}

Za stcsl. zveze $r b, r b, l b$, lb se uporabljajo v posameznih slovarjih refleksi prikazani v Tabeli 9. V SS, SJS in RCJM se zveze zapisujejo načeloma enako $\mathrm{z}$ izjemo mešanja polglasnikov, medtem ko se $\mathrm{v}$ RCJH zvezi $r b$ in $l b$ povsod poenotita $\mathrm{z} r b$, lb. Izjema je SDRJ, ki ločuje med zapisom psl. sonantičnih $b r, b r, b l, b l$ in nesonantičnih zvez $r b, r b, l b, l b$.

Tabela 9: Refleksi za stcsl. zveze $r b, r b, l b, l b$

\begin{tabular}{|c|c|c|c|c|c|c|}
\hline S. & SS & SJS & RCJH & RCJM & $\begin{array}{l}\text { SRJ (oz. } \\
\text { SRR) }\end{array}$ & SDRJ \\
\hline \multirow{4}{*}{$\begin{array}{l}\rho \mathrm{h}, \\
\Delta \mathrm{h}, \\
\rho \mathrm{b}, \\
\Delta \mathrm{b}\end{array}$} & $\begin{array}{l}\rho \mathrm{b}, \rho \mathrm{b}, \\
\Lambda \mathrm{b}, \Lambda \mathrm{b}\end{array}$ & $\begin{array}{l}\rho \mathrm{h}, \rho \mathrm{b}, \Lambda \mathrm{b}, \\
\Lambda \mathrm{b}\end{array}$ & $\rho \mathrm{b}, \lambda \mathrm{b}$ & $\begin{array}{l}\rho \mathrm{h}, \rho \mathrm{b}, \Lambda \mathrm{b}, \\
\Lambda \mathrm{b}\end{array}$ & $\begin{array}{l}\rho \mathrm{h}, \rho \mathrm{h}, \Lambda \mathrm{h}, \\
\Lambda \mathrm{b}\end{array}$ & $\begin{array}{l}\mathrm{b} \rho, \mathrm{b} \rho, \mathrm{b} \Lambda, \mathrm{b} \Lambda \\
\rho \mathrm{h}, \rho \mathrm{b}, \Lambda \mathrm{h}, \Lambda \mathrm{b}\end{array}$ \\
\hline & $\begin{array}{l}\text { врьтБТн СА, } \\
\text { врьщЖ СА, } \\
\text { врьтншн СА } \\
\text { ipf }\end{array}$ & $\begin{array}{l}\text { врътьттн сА, } \\
\text { връчЖ сА, } \\
\text { врътншн сА } \\
i p f\end{array}$ & $\begin{array}{l}\text { врьтьтн сє, } \\
\text { врьщог сє, } \\
\text { врьтншн сє ipf }\end{array}$ & 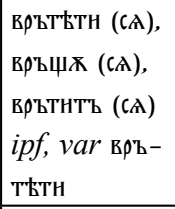 & $\begin{array}{l}\varnothing \text { । I SRR } \\
\text { врьтБтн сє, } \\
\text { врьщог сє, } \\
\text { врьтншь сє ipf }\end{array}$ & $\begin{array}{l}\text { вьР|ТБТНСА, } \\
\text {-ҮOКСА/ } \\
\text {-ШоКСА, } \\
\text {-ТНТЬСА ipf }\end{array}$ \\
\hline & $\begin{array}{l}\text { грьмьтн, } \\
\text { грьмиња, } \\
\text { грьмншн ipf }\end{array}$ & $\begin{array}{l}\text { грьмьтн, } \\
\text { грьмињх, } \\
\text { грьцншн ipf }\end{array}$ & $\begin{array}{l}\text { грьмьтн, } \\
\text {-млю, } \\
\text {-мншн ipf }\end{array}$ & $\begin{array}{l}\text { гръиьтн, } \\
\text {-мих, } \\
\text {-мнтъ ipf }\end{array}$ & $\begin{array}{l}\varnothing \text { | I SRR } \\
\text { грьмьтн, } \\
\text {-млю, -мншн } \\
\text { ipf }\end{array}$ & 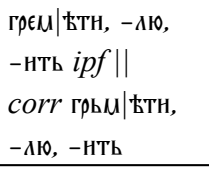 \\
\hline & $\begin{array}{l}\varnothing \| v . s u b \\
\text { АлъготръПА }\end{array}$ & $\begin{array}{l}\text { АлъготръПБтн, } \\
\text {-плњх, -пншн } \\
\text { ipf }\end{array}$ & $\begin{array}{l}\text { АльготрьпБТн, } \\
\text {-Плю, -Пншн } \\
\text { ipf }\end{array}$ & $\begin{array}{l}\text { АлъготръпБтн, } \\
\text {-пАх, -Пнтъ } \\
\text { ipf }\end{array}$ & $\begin{array}{l}\text { Алъотръпьтн, } \\
\text {-Плю, -Пншн } \\
\text { ipf }\end{array}$ & 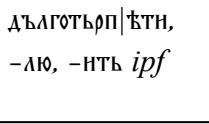 \\
\hline
\end{tabular}

\subsection{0}

Refleksi stcsl. zveze likvide in vokala v sredinskih zlogih so znotraj posameznih gesel zabeleženi v Tabeli 10. Stcsl. zveze likvide in vokala so ohranjene povsod, z izjemo SDRJ, kjer so za zvezo lě uporablja refleks le, pri oblikah z zvezama rě in ra pa so prisotne dubletne oblike, in sicer poleg re $(<r e ̌)$ in $r a$ še oblike s polnoglasjem ere, oro. 
Barbara Balantič: Glagoli v primerjalnem indeksu $k$ slovarjem obdelanem v okviru Komisije... FILOLOGIJA 69(2017), 1-21

Tabela 10: Refleksi stcsl. zveze likvide in vokala

\begin{tabular}{|c|c|c|c|c|c|c|}
\hline S. & SS & SJS & RCJH & RCJM & $\begin{array}{l}\text { SRJ (oz. } \\
\text { SRR) }\end{array}$ & SDRJ \\
\hline \multirow{4}{*}{$\begin{array}{l}\rho \mathrm{b}, \\
\Lambda \mathrm{k},\end{array}$} & $\begin{array}{l}\rho \mathrm{t}, \Lambda \mathrm{t}, \\
\rho d, \Lambda d\end{array}$ & $\begin{array}{l}\rho \mathrm{L}, \Lambda \mathrm{t}, \\
\rho d, \Lambda d\end{array}$ & $\begin{array}{l}\rho \mathrm{t}, \Lambda \mathrm{t}, \\
\rho d, \Lambda d\end{array}$ & $\begin{array}{l}\rho \mathrm{L}, \Lambda \mathrm{t}, \\
\rho d, \Lambda d\end{array}$ & $\begin{array}{l}\rho \mathrm{t}, \Lambda \text { 它, } \rho d, \\
\Lambda d\end{array}$ & $\rho E / E \rho E, \Delta E, \rho \Delta / 0 \rho 0, \Delta A$ \\
\hline & $\begin{array}{l}\text { врћАнТн, } \\
\text { врБЖАХ, } \\
\text { врҺдншн } \\
p f\end{array}$ & $\begin{array}{l}\text { врћАНТн, } \\
\text { врћжАХ, } \\
\text { врћдншн } \\
p f\end{array}$ & $\begin{array}{l}\text { врьднтн, } \\
\text { врћжАю, } \\
\text { врћдншн } \\
p f\end{array}$ & 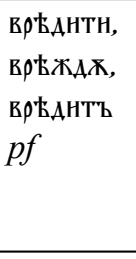 & $\begin{array}{l}\text { връднтн, } \\
\text { врЂждог, } \\
\text { врЂдншн } \\
p f \\
\|=S R R\end{array}$ & 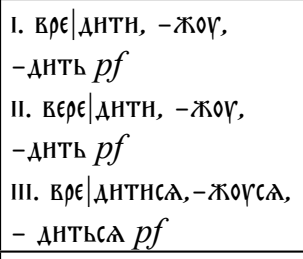 \\
\hline & $\begin{array}{l}\text { вльщтн, } \\
\text { влькх, } \\
\text { в Буєшн } \\
\text { ipf }\end{array}$ & 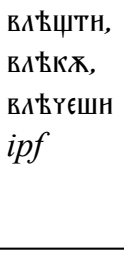 & 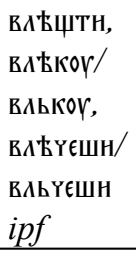 & 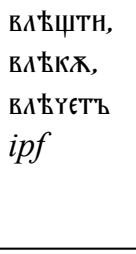 & 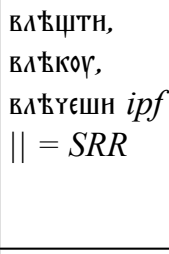 & 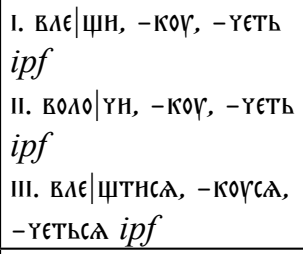 \\
\hline & $\begin{array}{l}\text { ГрадНТТ, } \\
\text { ГражАХ, } \\
\text { ГрадншШН } \\
\text { ipf }\end{array}$ & $\begin{array}{l}\text { ГраднТН, } \\
\text { ГражАХ, } \\
\text { Градншн } \\
\text { ipf }\end{array}$ & $\begin{array}{l}\text { ГрАднТН, } \\
\text {-жАю, } \\
\text {-дншн } \\
\text { ipf }\end{array}$ & $\begin{array}{l}\text { ГрадНТТ, } \\
\text { ГражАХ, } \\
\text { ГраднТТъ } \\
\text { ipf }\end{array}$ & $\begin{array}{l}\text { граднТн, } \\
\text { граждог, } \\
\text { градншн ipf } \\
\|=S R R\end{array}$ & 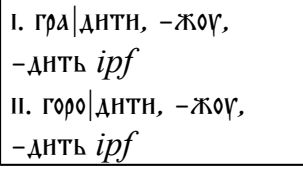 \\
\hline
\end{tabular}

\subsection{1}

Refleksi za stcsl. mehki soglasniki $r^{\prime}, l^{\prime}, n^{\prime}$ v zlogu z a so prikazani v Ta-

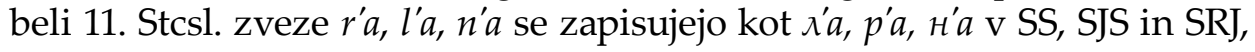
medtem ko se v RCJM za mehkimi soglasniki uporablja zapis z grafemom $\mathrm{b}-\lambda \mathrm{b}, \mathrm{p} \varpi, \mathrm{H} \varpi, \mathrm{v}$ RCJH pride do otrditve soglasnika $p a$ in poenotenja $l^{\prime} a$, $n^{\prime} a \mathrm{z} l a, n a$ in zapisa $\lambda a$ in $\mu a, \mathrm{v}$ SDRJ pa se uporabljaja zapis $\lambda^{\prime}, p^{\prime}, \mu^{\prime}$. 
Barbara Balantič: Glagoli v primerjalnem indeksu k slovarjem obdelanem v okviru Komisije... FILOLOGIJA 69(2017), $1-21$

Tabela 11: Stcsl. $r^{\prime}, l^{\prime}, n^{\prime}$ v zlogu z $a$

\begin{tabular}{|c|c|c|c|c|c|c|}
\hline s. & SS & SJS & $\mathrm{RCJH}$ & RCJM & $\begin{array}{l}\text { SRJ (oz. } \\
\text { SRR) }\end{array}$ & SDRJ \\
\hline \multirow{3}{*}{$\begin{array}{l}\rho, \\
\Lambda^{\prime}, \\
{ }_{H},\end{array}$} & АГд, рГд, нІа & Аाа, рґа, нІа & $\Lambda A, \rho d, \mathrm{H} \Delta$ & $\Delta \mathrm{\hbar}, \rho \mathrm{\hbar}, \mathrm{H}$ & Аाа, рґа, нाа & $\Lambda \mathrm{A}$, PA, HA \\
\hline & $\begin{array}{l}\text { жнБлґтн, } \\
\text {-влґањ, } \\
\text {-вдґаєшн } \\
\text { ipf }\end{array}$ & 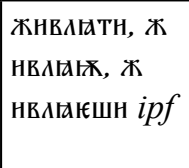 & $\begin{array}{l}\text { ЖНВАатн, } \\
\text {-аю, } \\
\text {-Аєшн ipf }\end{array}$ & 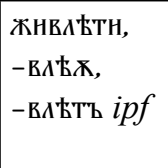 & $\begin{array}{l}\text { ЖНВлатн, } \\
\text {-вдаю, } \\
\text {-вдағшн ipf }\end{array}$ & $\varnothing$ \\
\hline & въСТАБАЮТТН & въСТАБАनТТН & вставАатН & въставаьТН & вьСТАБлІатН & $\begin{array}{l}\text { въZСТАВААТН } \\
\text { въZСТАВАATH } \\
\text { СА }\end{array}$ \\
\hline \multirow[b]{2}{*}{$a$} & Zатварнтатн & ZатварНТТН & zатваратн & ZатварБтн, & ZатвАрНТТН & ZатварАтН \\
\hline & $\begin{array}{l}\text { BъсланII } \\
\text { TH СA }\end{array}$ & въСАAHITTH CA & $\begin{array}{l}\text { всланатн } \\
\text { С€ }\end{array}$ & $\begin{array}{l}\text { въсAан'БтH } \\
\text { сA }\end{array}$ & $\begin{array}{l}\text { въсAанILTH } \\
\text { сA }\end{array}$ & $\begin{array}{l}\text { BъZCAAHATH } \\
\text { CA }\end{array}$ \\
\hline
\end{tabular}

\section{Morfološke razlike}

Grafemske spremembe so pogosto vplivale tudi na morfološke značilnosti. Morfološke razlike se kažejo skozi različne končnice ter skozi dubletne oblike.

\section{1}

Znotraj gesel so prisotne razlike v končnicah prikazane v Tabeli 12 . V SJS, SS, RCJH in SRJ je glagol gramatično identificiran $\mathrm{z}$ navedbo 1. in 2. osebe prezenta, medtem ko je v RCJM in SDRJ identificiran z navedbo 1 . in 3. osebe posameznega glagola.

Tabela 12: Razlike v končnicah

\begin{tabular}{|c|l|l|l|l|l|l|}
\hline s. & \multicolumn{1}{|c|}{ SS } & \multicolumn{1}{|c|}{ SJS } & RCJH & \multicolumn{1}{c|}{ RCJM } & $\begin{array}{l}\text { SRJ (oz. } \\
\text { SRR) }\end{array}$ & \multicolumn{1}{c|}{ SDRJ } \\
\hline $\begin{array}{c}\text { 1. prez. } \\
\text { oseba }\end{array}$ & $-\mathrm{x}$ & $-\mathrm{x}$ & - or & $-\mathrm{x}$ & - or & - or \\
\hline $\begin{array}{c}\text { 3. prez. } \\
\text { oseba }\end{array}$ & $\begin{array}{l}\text { NI } \\
\text { PODATKA }\end{array}$ & $\begin{array}{l}\text { NI } \\
\text { PODATKA }\end{array}$ & $\begin{array}{l}\text { NI } \\
\text { PODATKA }\end{array}$ & $-\mathrm{Tr}$ & $\begin{array}{l}\text { NI } \\
\text { PODATKA }\end{array}$ & $-\mathrm{T \textrm {t }}$ \\
\hline
\end{tabular}


Barbara Balantič: Glagoli v primerjalnem indeksu k slovarjem obdelanem v okviru Komisije... FILOLOGIJA 69(2017), 1-21

V 1. osebi prezenta se zaradi denazalizacije $-q>-u$ v RCJH, SRJ in SDRJ pojavljajo končnice $\mathrm{z}-u$, medtem ko so $\mathrm{v}$ ostalih slovarjih ohranjene končnice $\mathrm{z}-Q$. $\mathrm{V} 2$ 2. osebi prezenta med oblikami posameznih slovarjev ni razlik. V 3. osebi se v RCJM pojavlja stcsl. končnica -tø, medtem ko ima SDRJ oblike s končnico -tb.

\section{2}

Če pogledamo pobližje posamezne prezentove vrste, ki so prikazane v Tabeli 13, 14, 15, 16 in 17, opazimo pri nekaterih še dodatne razlike med posameznimi slovarji.

Razen že omenjenih končnic, v spregatvi 1. prezentove vrste ni opaziti dodatnih razlik med posameznimi slovarji.

Tabela 13: 1 . prezentova vrsta

\begin{tabular}{|c|c|c|c|c|c|c|}
\hline S. & SS & SJS & $\mathrm{RCJH}$ & RCJM & $\begin{array}{l}\text { SRJ (oz. } \\
\text { SRR) }\end{array}$ & SDRJ \\
\hline $\begin{array}{l}\text { 1. prez. } \\
\text { vrsta }\end{array}$ & $\begin{array}{l}-Х, \\
-\epsilon Ш H\end{array}$ & $\begin{array}{l}-X, \\
-\epsilon Ш H\end{array}$ & -or, -єШН & $-X,-\epsilon T^{\prime \prime}$ & -Or, -єШН & $-O Y-\epsilon T h$ \\
\hline $\begin{array}{c}\text { a. } \\
\text { razred }\end{array}$ & $\begin{array}{l}\text { ГрАстн, } \\
\text { ГрААХ, } \\
\text { ГрААєшн } \\
\text { ipf }\end{array}$ & $\begin{array}{l}\text { ГрАстн, } \\
\text { ГрААХ, } \\
\text { ГрААєшН } \\
\text { ipf }\end{array}$ & $\begin{array}{l}\text { ГрєстН }{ }^{2}, \text { ГрєАОҮ, } \\
\text { ГрєАєШН / } \\
\text { ГрєАєШЬ еt } \\
\text { ГрєМь, ГрєШН/ } \\
\text { ГрєШь ipf }\end{array}$ & $\begin{array}{l}\text { ГрАСТН, } \\
\text { ГрААХ, } \\
\text { ГрААЕТТ ipf }\end{array}$ & $\begin{array}{l}\text { ГрєСТН, ГрєАОГ, } \\
\text { ГрєАєШН ipf }\end{array}$ & $\begin{array}{l}\text { ГрА|СТн, -АОГ, } \\
\text {-АєТь ipf }\end{array}$ \\
\hline $\begin{array}{c}\text { b. } \\
\text { razred }\end{array}$ & $\begin{array}{l}\text { ГъНАТн, } \\
\text { жєНХ, } \\
\text { жєнєШН } \\
\text { ipf }\end{array}$ & $\begin{array}{l}\text { Гънатн, } \\
\text { жєнж, } \\
\text { жєнєшн ipf }\end{array}$ & $\begin{array}{l}\text { гнатн, женоү, } \\
\text { жєнєшн et } \\
\text { рєноү, } \\
\text { рєнєшн ipf }\end{array}$ & $\begin{array}{l}\text { Гънатн, } \\
\text { ЖєнХ, } \\
\text { жєнєТъ ipf }\end{array}$ & $\begin{array}{l}\text { гьнатн, } \\
\text { жєноү, } \\
\text { жєнєшн ipf }\end{array}$ & $\begin{array}{l}\text { ГъНАТн, } \\
\text { жєноҮ, } \\
\text { жєнєТЬ ipf }\end{array}$ \\
\hline
\end{tabular}

Ravno tako tudi v 2. prezentovi vrsti, razen že omenjenih končnic, ni opaziti dodatnih morfoloških razlik znotraj gesel. 
Barbara Balantič: Glagoli v primerjalnem indeksu k slovarjem obdelanem v okviru Komisije... FILOLOGIJA 69(2017), $1-21$

Tabela 14: 2. prezentova vrsta

\begin{tabular}{|c|c|c|c|c|c|c|}
\hline s. & SS & SJS & $\mathrm{RCJH}$ & RCJM & $\begin{array}{c}\text { SRJ (oz. } \\
\text { SRR) }\end{array}$ & SDRJ \\
\hline $\begin{array}{l}2 . \\
\text { prez. } \\
\text { vrsta }\end{array}$ & $\begin{array}{l}-H \mathrm{X}, \\
-\mathrm{H} \in \mathrm{WH}\end{array}$ & $\begin{array}{l}-H \text { Х, } \\
-н \in Ш H\end{array}$ & $\begin{array}{l}-\mathrm{HOY,} \\
-\mathrm{H} \in ш н\end{array}$ & $\begin{array}{l}-H X, \\
-H \in T h \mathrm{~h}\end{array}$ & $\begin{array}{l}\text { - НОY, } \\
\text { - Нєшн }\end{array}$ & -HOY, - - HETL \\
\hline $\begin{array}{l}\text { a. } \\
\text { razred }\end{array}$ & $\begin{array}{l}\text { ВЪСТАГНКТН, } \\
- \text {-НХ, -НєШН } \\
p f\end{array}$ & $\begin{array}{l}\text { ВЪСТАГНЖТН, } \\
\text {-НХ, -НЕШН } \\
\text { pf ] SJS5 } \\
\text { corr } \\
\text { var ad въ- } \\
\text { СТАГНХТН СА } \\
\end{array}$ & $\begin{array}{l}\text { встегноүтн, } \\
\text {-ноү, } \\
\text {-нєшн } p f\end{array}$ & $\begin{array}{l}\text { вЪСТАГНХ } \\
\text { ТН, } \\
- \text {-НЖ, -НЕТЪ } \\
p f\end{array}$ & $\begin{array}{l}\varnothing \| \text { || SRR } \\
\text { вьстєГ- } \\
\text { ноүтн, } \\
\text {-ног, } \\
\text {-нєшн } p f\end{array}$ & $\begin{array}{l}\text { въZТТАГн|оүтн, } \\
\text {-оY, -єТь } p f\end{array}$ \\
\hline $\begin{array}{l}\mathrm{b} . \\
\text { razred }\end{array}$ & $\varnothing$ & $\begin{array}{l}\text { върннХтн, } \\
\text {-рннж, } \\
\text {-рннєшн } p f\end{array}$ & $\begin{array}{l}\text { врнноүтн, } \\
\text {-ног, } \\
\text {-нєшн } p f\end{array}$ & 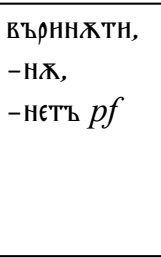 & $\begin{array}{l}\varnothing \| S R R \\
\text { вьрнноүтн, } \\
\text {-рнног, } \\
\text {-рннєшн } p f\end{array}$ & $\begin{array}{l}\text { върнн/оүтн, } \\
\text {-ноү, } \\
\text {-єТь } p f \\
\text { върнн/оүтнсА, } \\
\text {-ноүсА, -єтьСА } \\
\text { pf }\end{array}$ \\
\hline
\end{tabular}

V 3. prezentovi vrsti v 1. osebi prezenta se zaradi denazalizacije -jo > -ju v RCJH, SRJ in SDRJ pojavljajo končnice $\mathrm{z}-j u$, medtem ko so v ostalih slovarjih ohranjene končnice $\mathrm{z}-j q$, z izjemo RCJM, ki tako v končnici za 1. osebo kot v končniški priponi za 3 . osebo vsebuje nejotirana grafema $n$ in $\mathrm{\epsilon}$, saj omenjeni slovar ne uporablja jotiranih grafemov (na predhodnjih soglasnikih pa je sicer opaziti posledico jotacije, npr. гыбати, -блж, -блєтъ), prav tako tudi RCJH v končniški priponi za 2. osebo namesto jotiranega grafema it uporablja grafem $\in$ [je].

Tabela 15: 3. prezentova vrsta

\begin{tabular}{|c|c|c|c|c|c|c|}
\hline S. & SS & SJS & RCJH & RCJM & $\begin{array}{l}\text { SRJ } \\
\text { (oz. } \\
\text { SRR) }\end{array}$ & SDRJ \\
\hline $\begin{array}{l}3 . \\
\text { prez. } \\
\text { vrsta }\end{array}$ & 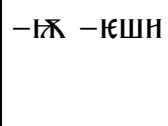 & $-\Vdash 木$ - & $-\mapsto 0-€ Ш Н$ & $-X-\epsilon \mathrm{T} \mathrm{b}$ & $\begin{array}{l}-10 \\
-16 Ш H\end{array}$ & $-10-£ T h$ \\
\hline $\begin{array}{l}\text { a. } \\
\text { razred }\end{array}$ & $\begin{array}{l}\text { АҺАатн,- } \\
\text { ањ , -аєшн } \\
\text { ipf }\end{array}$ & 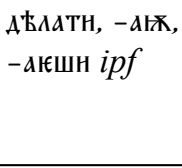 & $\begin{array}{l}\text { А'Аатн, -аю, } \\
- \text {-Ашн ipf }\end{array}$ & 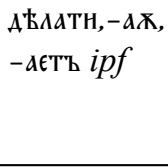 & $\begin{array}{l}\text { дћлатн, } \\
\text { - Аю, } \\
\text { - Аюшн } \\
\text { ipf }\end{array}$ & 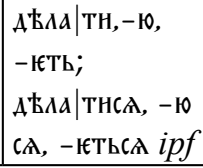 \\
\hline
\end{tabular}


Barbara Balantič: Glagoli v primerjalnem indeksu $k$ slovarjem obdelanem v okviru Komisije... FILOLOGIJA 69(2017), 1-21

\begin{tabular}{|c|c|c|c|c|c|c|}
\hline s. & SS & SJS & RCJH & RCJM & $\begin{array}{l}\text { SRJ } \\
\text { (oz. } \\
\text { SRR) }\end{array}$ & SDRJ \\
\hline $\begin{array}{c}\mathrm{b} . \\
\text { razred }\end{array}$ & $\begin{array}{l}\text { zнатн, } \\
\text { zнањк, } \\
\text { знањшн ipf }\end{array}$ & $\begin{array}{l}\text { zнатн, zнањх, } \\
\text { zнаюшн ipf }\end{array}$ & $\begin{array}{l}\text { Zнатн, } \\
\text { знаю, } \\
\text { zнаєшн ipf }\end{array}$ & $\begin{array}{l}\text { zнатн zнак, } \\
\text { zнаєтъ ipf }\end{array}$ & \begin{tabular}{|l} 
zнатн, \\
zнаю, \\
zнаюшн \\
ipf \\
\end{tabular} & $\begin{array}{l}\text { zна|тн, -ю, } \\
\text {-єть ipf }\end{array}$ \\
\hline
\end{tabular}

V 4. prezentovi vrsti do razlik prihaja le v 1. osebi prezenta, kjer SS,SJS uporabljata jotirani nosnišni grafem -ıx, RCJH nejotirani nosniški grafem -ঙ, ostali pa denazalizirani jotirani grafem -Ю (enako kot v 3. prezentovi vrsti).

Tabela 16: 4. prezentova vrsta

\begin{tabular}{|c|c|c|c|c|c|c|}
\hline S. & SS & SJS & $\mathrm{RCJH}$ & RCJM & $\begin{array}{l}\text { SRJ (oz. } \\
\text { SRR) }\end{array}$ & SDRJ \\
\hline $\begin{array}{l}\text { 4. prez. } \\
\text { vrsta }\end{array}$ & $\begin{array}{l}-1 x \\
-н ш H\end{array}$ & $\begin{array}{l}-1 \times \\
-н ш н\end{array}$ & $-ю-$-нШН & $-\mathrm{X},-\mathrm{HTh}$ & -ю, -нШН & $-ю,-$ НTh \\
\hline $\begin{array}{c}\text { a. } \\
\text { razred }\end{array}$ & $\begin{array}{l}\text { гоннтн, } \\
\text {-ніх, } \\
\text {-нншн ipf }\end{array}$ & $\begin{array}{l}\text { гоннтн, } \\
\text {-ніх, } \\
\text {-нншн ipf }\end{array}$ & $\begin{array}{l}\text { гоннтн, } \\
\text {-ню, } \\
\text {-нншн ipf }\end{array}$ & $\begin{array}{l}\text { гоннтн, } \\
\text {-нж, } \\
\text {-ннть ipf }\end{array}$ & $\begin{array}{l}\text { гоннтн, -ню, } \\
\text {-нншн ipf }\end{array}$ & $\begin{array}{l}\text { гон|нТН, -ю, } \\
\text {-НТь ipf } \\
\text { ГОН|НТНСА, } \\
\text { - ЮСА, -НТьСА } \\
\text { ipf }\end{array}$ \\
\hline $\begin{array}{c}\text { b. } \\
\text { razred }\end{array}$ & $\begin{array}{l}\text { zьрьтн, } \\
\text { zьрюж, } \\
\text { зьрншн ipf }\end{array}$ & $\begin{array}{l}\text { zьрьтн, } \\
\text { ъьрюж, } \\
\text { зьрншн ipf }\end{array}$ & $\begin{array}{l}\text { zрьтн, зрю, } \\
\text { зрншн ipf }\end{array}$ & $\begin{array}{l}\text { zьрьтн, } \\
\text { ъьрх, } \\
\text { зьрнть ipf }\end{array}$ & $\begin{array}{l}\text { दрьтн, -рю, } \\
\text {-рншн ipf \| } \\
\text { SRR var } \\
\text { Zьрьтн, -рю, } \\
\text {-рншн }\end{array}$ & $\begin{array}{l}\text { 乙ьрь| } \text { тн }^{2}-ю, \\
\text {-нТь ipf; } \\
\text { 乙ьрь|Тн -ю, } \\
\text {-нТь ipf }\end{array}$ \\
\hline
\end{tabular}

Pri atematskih glagolih razen dubletnih končnic -si, -ši in pri določenih glagolih tudi -šb v RCJH za 2. osebo, ni opaziti drugih spregatvenih razlik med posameznimi slovarji. 
Barbara Balantič: Glagoli v primerjalnem indeksu k slovarjem obdelanem v okviru Komisije... FILOLOGIJA 69(2017), $1-21$

Tabela 17: Atematski glagoli

\begin{tabular}{|c|c|c|c|c|c|c|}
\hline s. & SS & SJS & RCJH & RCJM & $\begin{array}{c}\text { SRJ (oz. } \\
\text { SRR) }\end{array}$ & SDRJ \\
\hline & $-\mathrm{Mb},-\mathrm{CH}$ & $-M \mathrm{~L},-\mathrm{CH}$ & $\begin{array}{l}-M \mathrm{~b},-\mathrm{CH} / \\
\text { шн / шь }\end{array}$ & $-M \mathrm{~b},-C \mathrm{CTh}$ & $\begin{array}{l}-\mu \mathrm{b}, \\
-\mathrm{CH}\end{array}$ & $-M \mathrm{~b},-C \mathrm{TL}$ \\
\hline $\begin{array}{c}A \\
t\end{array}$ & $\begin{array}{l}\text { АATH, АAML, } \\
\text { ААCH } p f\end{array}$ & $\begin{array}{l}\text { ААТН, АAML, } \\
\text { ААCH } p f\end{array}$ & $\begin{array}{l}\text { ААТН, ААМь, } \\
\text { АACH vel ААШН } \\
\text { pf }\end{array}$ & $\begin{array}{l}\text { ААТН, АAMь, } \\
\text { ААСТъ } p f\end{array}$ & $\begin{array}{l}\text { ААТН, } \\
\text { ААMь, } \\
\text { ААСН } p f\end{array}$ & 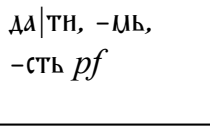 \\
\hline $\begin{array}{c}\mathrm{e} \\
\mathrm{m} \\
\mathrm{a} \\
\mathrm{t} \\
\mathrm{s} \\
\mathrm{k} \\
\mathrm{i}\end{array}$ & 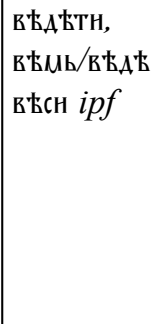 & 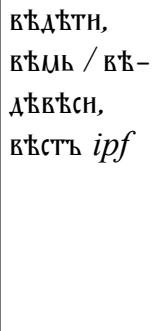 & 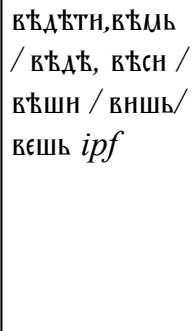 & 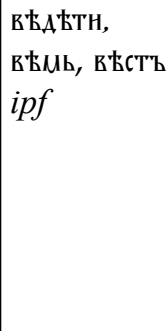 & 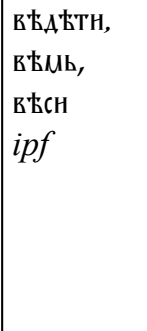 & 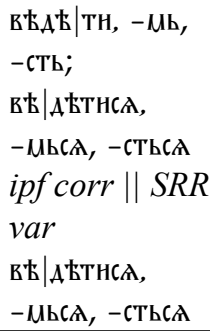 \\
\hline
\end{tabular}

\section{3}

Znotraj gesel se pri določenih glagolih zaradi različnih možnih spregatev posameznega glagola pojavljajo dubletne oblike. Običajno gre za dvojnično spregatev znotraj ene prezentove vrste, pojavljajo pa se tudi glagoli z dvojničnimi spregatvami različnih prezentovih vrst.

Dubletne oblike se pogosto pojavljajo pri posameznih glagolih 3. prezentove vrste, $v$ Tabeli 18 je prikazan primer dubletne oblike glagola vęza$t i$ - po SS, SJS in SDRJ je glagol možno spregati po 3. prezentovi vrsti tako a. razreda kot b. razreda, v RCJH, RCJM in SRJ pa se glagol sprega le po 3. prezentovi vrsti b. razreda.

Tabela 18: Primer dubletne oblike 3. prezentove vrste

\begin{tabular}{|c|c|c|c|c|c|c|}
\hline S. & SS & SJS & RCJH & RCJM & $\begin{array}{l}\text { SRJ (oz. } \\
\text { SRR) }\end{array}$ & SDRJ \\
\hline $\begin{array}{l}\text { 3. a } \\
\text { prez. }\end{array}$ & $\begin{array}{l}\text { 3. prez. } \\
\text { b in } \\
\text { 3. prez. a }\end{array}$ & $\begin{array}{l}\text { 3. prez. b in } \\
\text { 3. prez. a }\end{array}$ & 3. prez. b & 3. prez. b & 3. prez. b & $\begin{array}{l}\text { 3. prez. b (+ refl. } \\
\text { obl.) in 3. prez. A }\end{array}$ \\
\hline $\begin{array}{l}\text { 3. b } \\
\text { prez. }\end{array}$ & 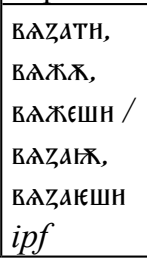 & 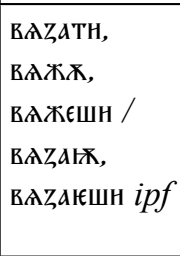 & $\begin{array}{l}\text { вєZатн, } \\
\text { вєжоү, } \\
\text { вєЖєШн } \\
\text { ipf }\end{array}$ & $\begin{array}{l}\text { вАһАТН, } \\
\text { вАЖХ, } \\
\text { вАжЕТЋ } \\
\text { ipf }\end{array}$ & $\begin{array}{l}\text { вєZатн, } \\
\text { вєжог, } \\
\text { вєжєшн ipf }\end{array}$ & 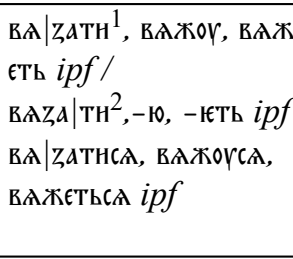 \\
\hline
\end{tabular}


Barbara Balantič: Glagoli v primerjalnem indeksu $k$ slovarjem obdelanem v okviru Komisije... FILOLOGIJA 69(2017), 1-21

Drug primer dubletnih oblik prikazuje primer glagola vъmetati v Tabeli 19, kjer prihaja še do večjega števila različnih glagolskih spregatev. V SS se glagol sprega po 1. prezentovi vrsti, medtem ko SJS, RCJH, RCJM spregajo glagol po obeh razredih 3. prezentove vrste, SRJ po 3. prez. vrsti a. razreda, SDRJ pa po 3. prez. vrsti b. razreda, obenem pa še navaja dubletne oblike zaradi dvojnične glasovne oblike -št- in - ̌č-

Tabela 19: Primer dubletne oblike 3. in 1. prezentove vrste

\begin{tabular}{|c|c|c|c|c|c|c|}
\hline S. & SS & SJS & RCJH & RCJM & $\begin{array}{c}\text { SRJ (oz. } \\
\text { SRR) }\end{array}$ & SDRJ \\
\hline \multirow[b]{2}{*}{$\begin{array}{c}\text { 1.a } \\
\text { prez., } \\
\text { 3. a } \\
\text { prez. } \\
\text { in } \\
\\
\text { 3. b } \\
\text { prez. }\end{array}$} & 1. prez. b & $\begin{array}{l}\text { 3. prez. a in } \\
\text { 3. prez b }\end{array}$ & $\begin{array}{l}\text { 3. prez. a (2 } \\
\text { obl. - }- \text {-/-t-) } \\
\text { in 3. prez.b }\end{array}$ & $\begin{array}{l}\text { 3. prez. } \\
\text { a in } \\
\text { 3. prez. b }\end{array}$ & 3. prez. a & $\begin{array}{l}\text { 3. prez. } \\
\text { b ( } 2 \text { obl. } \\
- \text { - -/-џ-) + } \\
\text { refl. obl. }\end{array}$ \\
\hline & 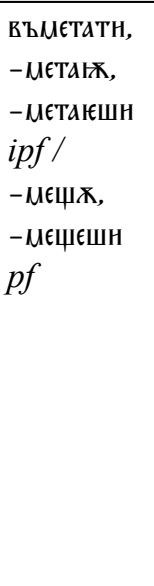 & 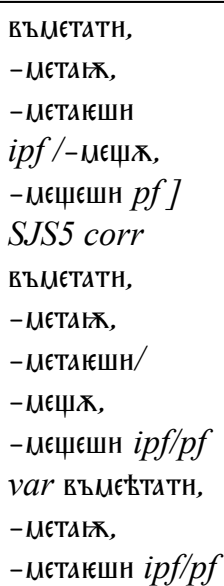 & 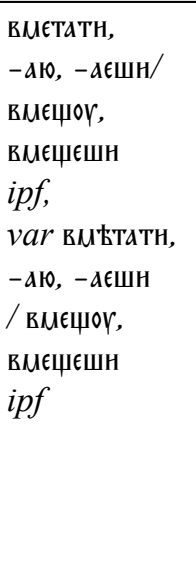 & 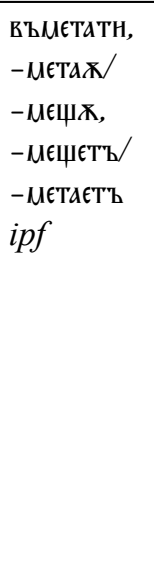 & $\begin{array}{l}\text { вьМЕтатН, } \\
\text { - МєТАю, } \\
\text { - МєтаюЕН } \\
\text { ipf }\end{array}$ & 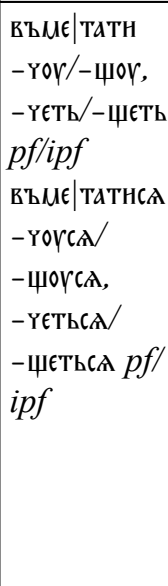 \\
\hline
\end{tabular}

\section{Refleksivizirane glagolske oblike}

Refleksivizirane oblike posameznih glagolov se navajajo bodisi kot samostojno geslo bodisi kot variantna oblika. Refleksivizirane oblike posameznih glagolov niso vedno prisote $\mathrm{v}$ vseh slovarjih, $\mathrm{v}$ enih primerih so navedene $\mathrm{v}$ enih slovarjih, $\mathrm{v}$ drugih primerih pa $\mathrm{v}$ drugih, najpogosteje jih navaja SDRJ, in sicer kot variante oblike. V Tabeli 20 je prikazanih nekaj primerov. 
Barbara Balantič: Glagoli v primerjalnem indeksu k slovarjem obdelanem v okviru Komisije... FILOLOGIJA 69(2017), $1-21$

Tabela 20: Refleksivizirane glagolske oblike

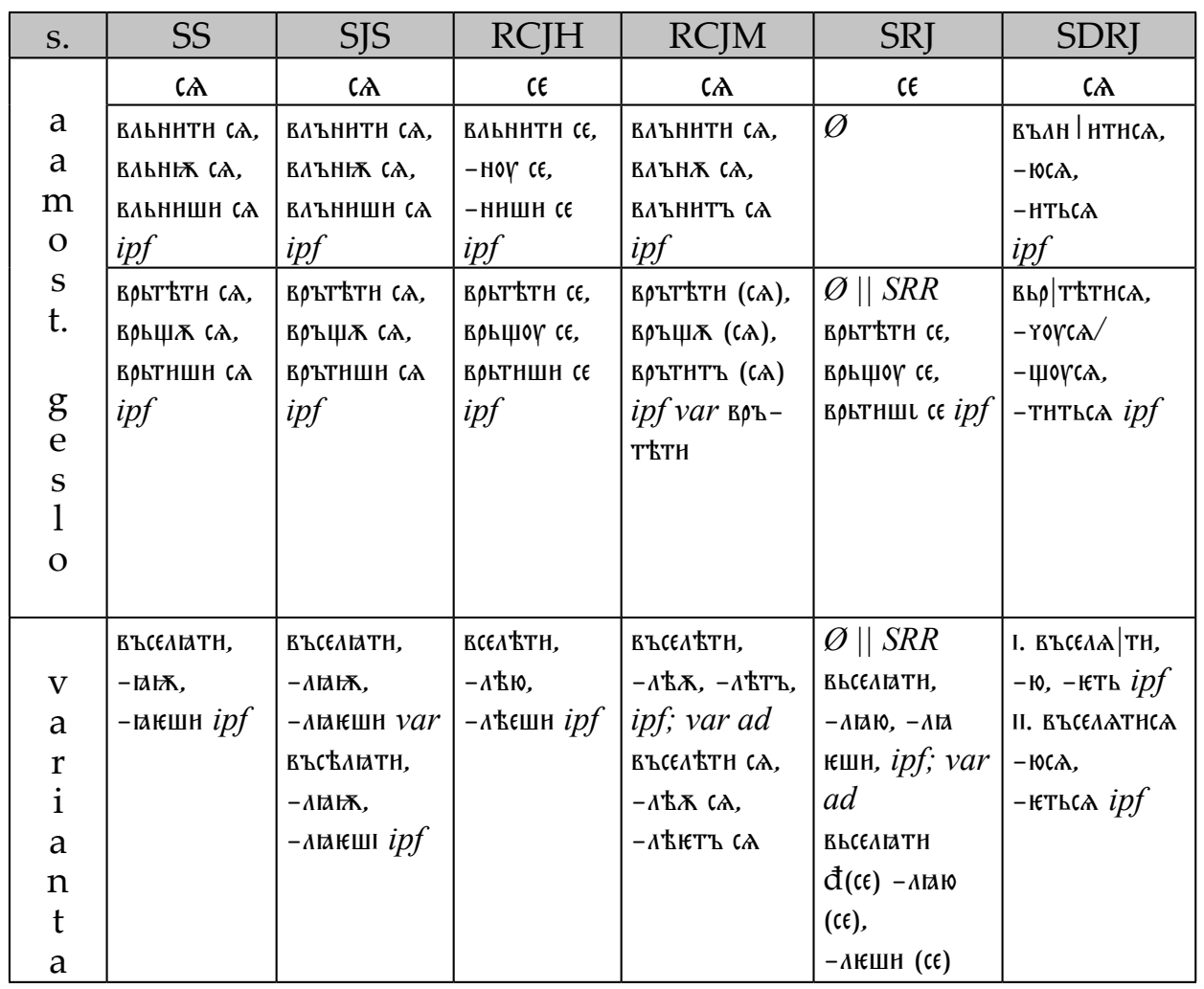

\section{Glagolski aspekt}

Pri nekaterih glagolih se pojavljajo razlike pri določitvi glagolskega aspekta. V Tabeli 21 je prikazanih nekaj primerov. Največkrat se glagolski aspekt določenega glagola razlikuje le v posameznem slovarju, kot npr. pri glagolu vъnušiti, kjer se glagolski aspekt razlikuje le v SDRJ. Nekajkrat se pojavi neskladnost tudi med večimi slovarji, npr. pri glagolu gybnoti, kjer del slovarjev glagolu določa nedovršnost, del pa dovršnost. 
Barbara Balantič: Glagoli v primerjalnem indeksu $k$ slovarjem obdelanem v okviru Komisije... FILOLOGIJA 69(2017), 1-21

Tabela 21: Glagolski aspekt

\begin{tabular}{|c|c|c|c|c|c|c|}
\hline S. & SS & SJS & RCJH & RCJM & $\begin{array}{l}\text { SRJ } \\
\text { (oz. } \\
\text { SRR) }\end{array}$ & SDRJ \\
\hline ГЫБнХтн & $i p f / p f$ & ipf, semel pf & $p f$ & $i p f$ & $p f$ & $p f$ \\
\hline Благословнтн & pflipf & $p f$ lipf & $p f$ & pflipf & $p f$ & $p f / i p f$ \\
\hline въсылдтн & $i p f$ & ipf & ipf & ipf & $i p f$ & $p f$ \\
\hline вЊроватн & $i p f / p f$ & $i p f / p f$ & $i p f / p f$ & $i p f$ & $i p f$ & $i p f$ \\
\hline ААроватн & $i p f / p f$ & $i p f / p f$ & $i p f / p f$ & $i p f / p f$ & $i p f$ & $i p f$ \\
\hline АОВОАНTH СA & $\varnothing$ & $i p f / p f$ & $\emptyset$ & pf/ipf & $i p f$ & $p f$ \\
\hline ЖATH ${ }^{2}$ & $i p f$ & $i p f$ & $i p f$ & $i p f$ & $i p f$ & $p f$ \\
\hline zactorath & $i p f$ & $i p f$ & ipf & $i p f$ & $p f$ & $i p f$ \\
\hline ZАСЪВБАБТТАЬСТВОВАТН & pf/ipf & pflipf & pf/ipf & pf/ipf & $i p f$ & $p f$ \\
\hline въскрђшатн & $i p f$ & $i p f$ & ipf & ipf & $i p f$ & $p f$ \\
\hline въноүшнтн & $p f$ & $p f$ & $p f$ & $p f$ & $p f$ & $i p f$ \\
\hline
\end{tabular}

\section{Sklep}

Pregled informacij o starocerkvenoslovanskih glagolih v indeksu kaže na mnoge razlike med posameznimi slovarji. S stališča informacij o glagolskih oblikah tako indeks predstavlja pomembno sredstvo pri preučevanju le-teh, saj uporabniku posreduje informacije večih redakcij na enem mestu. Nazorno prikaže uzus posameznih slovarjev in redakcij ter razlike $\mathrm{v}$ normalizaciji. Znotraj gesel so prisotne razlike na večih jezikovnih ravninah. Opaziti je veliko grafemskih razlik - npr. razlike v zapisu stcsl. zvez $r b, r b, l b, l b$ (SDRJ razlikuje zapis psl. sonantičnih $r r, b r, b l, b l$ in nesonantičnih zvez $r b, r b, l b, l b)$, razlike $\mathrm{v}$ zapisu zveze likvide in vokala v sredinskih zlogih (v SDRJ dubletna oblika s polnoglasjem ere, oro), razlike $\mathrm{v}$ zapisu zvez $r^{\prime} a, l^{\prime} a, n^{\prime} a$ (v RCJM zapis $\lambda \varpi, \mathrm{p}$, $\mathrm{H}$, , v zapis SDRJ $\lambda^{\prime}, p^{\prime}, \mu^{\prime}, \mathrm{v}$ RCJH otrditev soglasnika $p a$ ), razlike $\mathrm{v}$ zapisu jotiranih grafemov (v RCJH namesto

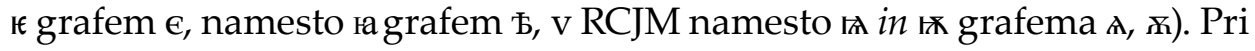
nekaterih določenih grafemskih razlikah pa si lahko upamo trditi, da so nastale pod vplivom določenih glasoslovnih sprememb, npr. sovpad y z i (v RCJH), denazalizacija nosnikov (v RCJH, SRJ in SDRJ), vokalizacija, ošibitev, onemitev (v RCJH) in sovpad polglasnikov (v RCJH, SRJ), soglasniške spremembe - prehod dz > z (v RCJH, SRJ, SDRJ), št, žd > č, ž (v SDRJ), sklopa -zdr- > -zr- (v RCJH, SRJ, SDRJ). Morfološke razlike, ki so večinoma nastale pod vplivom glasoslovnih sprememb pa se kažejo skozi različne 
Barbara Balantič: Glagoli v primerjalnem indeksu k slovarjem obdelanem v okviru Komisije... FILOLOGIJA 69(2017), $1-21$

podobe končnic (npr. v RCJH, SRJ in SDRJ končnica - $u$ za 1. osebo prezenta (nastala kot posledica denazalizacije $-Q>-u$ ) ter v RCJM končnica $-\check{z}$ za 1. osebo 3. in 4. prezentove vrste in končniška pripona -€тъ za 3. osebo 3. prezentove vrste, kot posledica uporabe nejotiranih grafemov tudi za jotirane foneme in $\mathrm{v}$ RCJH dubletna končnica $-s i$, -ši in -šb pri atematskih glagolih za 2. osebo) in dubletne oblike (najpogosteje pri glagolih 3. prezentove vrste, ki se lahko spregajo tako po spregatvi a. razreda kot b., v redkih primerih pa se pojavijo tudi glagoli s spregatvami večih različnih prezentovih vrst). Pri določenih glagolih je opaziti razlike tudi v tem, da refleksivizirane oblike posameznih glagolov niso vedno prisote $\mathrm{v}$ vseh slovarjih in da se pri nekaterih glagolih pojavljajo tudi razlike pri določitvi glagolskega aspekta. Na podlagi vseh pridobljenih informacij o starocerkvenoslovanskih glagolih lahko trdimo, da indeks predstavlja izčrpen register starocerkvenoslovanskega leksikografskega korpusa in nam ponuja veliko možnosti za nadaljne raziskave. 
Barbara Balantič: Glagoli v primerjalnem indeksu k slovarjem obdelanem v okviru Komisije... FILOLOGIJA 69(2017), 1-21

\title{
Literatura
}

Аванесов Р. И. (Гл. ред.; I-IV), Аванесов Р. И., У луханов И. С. (Гл. ред.; V), Крысько В. Б. (Га. ред.; VI-X). 1988-2013. Словарь древнерусского языка (XI-XIV вв.) I-X: a-svbtětisę. РАН. Институт русского языка, Москва. (SDRJ)

Цейтлин, Р. М. (ред.); Вечерка, Р.; Блахова, Е. 1994 (2. изд. 1999). Старославянский словарь (по рукописям X-XI веков). Москва. (SS)

Kurz, Josef (hl. red. I-III.), Hauptová, Zoe (hl. red. IV). 1966-1997. Slovník jazyka staroslověnského. Praha; reprint: Словарь старославянского языка Санкт-Петербург 2006. (SJS)

Nazor, Anica (zn. red.). 2000, 2014. Rječnik crkvenoslavenskoga jezika hrvatske redakcije I. a-vrěds, II. vrědvns-zapovědnica, sv. 11-20. Zagreb. (RCJH)

Рибарова, Зденка (Гл. Уред.). 2006 I, 2008-2013ㅍ. Речник на црковнословенскиот јазик од македонска редакција - I. Вовед. a-b., II. v-vъsklaněti sę, св. 8-11. Скопје. (RCJM)

Ribarova, Zdenka (red.) 2011. Srovnávací index k slovníkům zpracovávaným $v$ rámci Komise pro církevněslovanské slovníky. Pracovní výtisk. vlъkovъ—d, ž, dz, z. Glavna urednica. Praha - Ljubljana, 2011.

Рибарова, Зденка (ред.). 2015. Споредбен индекс кон речниците обработувани во рамките на комисијата за ирковнословенски речници при мкк. Редактор Зденка Рибарова. Skopje 2015. http://ical.manu.edu. mk/books/Sporedben\%20indeksMANU.pdf, prenos 27. 9. 2017.

Савић, В. 2007. Српскословенски речник јеванђела. пробна свеска. Уредник Г. Јовановић, Београд . (SRJ)

\section{Verbs in The Comparative Index Towards The Dictionaries Produced Under The Commission For Old Church Slavonic Lexicology And Lexicography At Ics}

\begin{abstract}
The paper focuses on information about Old Church Slavonic verbs, that can be gained in The Comparative Index Towards The Dictionaries Produced Under The Commission For Old Church Slavonic Lexicology And Lexicography At Ics (so-called Srovnávací index $k$ slovníkuim zpracovávaným v rámci Komise pro církevněslovanské slovníky u MKS; ed. Zdenka Ribarova, 2007-), which in one place from comparative point of view unites and presents among other different images of verbs or verb forms (of individual Church Slavonic recensional dictionaries (includes: Старославянский словарь (=SS; after manuscripts X.XI. c.; Moscow 1994), Slovník jazyka staroslověnského (= SJS; Prague 1958-1997),
\end{abstract}


Barbara Balantič: Glagoli v primerjalnem indeksu k slovarjem obdelanem v okviru Komisije... FILOLOGIJA 69(2017), $1-21$

Rječnik crkvenoslavenskoga jezika hrvatske redakcije (= RCJH; Zagreb, from 1991), Речник на ирковнословенскиот јазик од македонска редакција (= RCJM; Skopje, from 2006), Речник ирквенословенског језика српске редакције и Српско-словенског јеванђельског речника (= SRJ; after unissued index, Belgrade) and Словарь древнерусского языка (XI.-XIV. вв.) (=SDRJ; Moscow, 2007-). Within entries the differences are noticed in several linguistic levels. The most differences we notice in graphemic level, where different graphems appear for the same phoneme and are in certain cases reflection of certain phonetic changes (for example denazalization, unification or loss of yers, unification ы with и etc). These differences and changes often affect the morphological characteristics (eg. different endings, doublet forms). We can also notice some differences regarding reflexivised forms and in determination of verbal aspect. Judging by the results this Index presents the most exhaustive register of Old Slavonic and Old Church Slavonic lexicographic corpus and offers us many possibilities for further research.

Ključne besede: glagol, primerjalna paleoslavistična leksikografija, cerkvenoslovanski slovarji, starocerkvenoslovanski jezik, cerkvenoslovanske redakcije

Key words: verb, Comparative paleoslavistic lexicography, Church Slavonic dictionaries, Old Church Slavonic language, Church Slavonic recensions 
